\title{
Case of Strongyloides hyperinfection syndrome
}

\author{
Kevin Kuriakose, ${ }^{1}$ Kelly Carpenter, ${ }^{2}$ Celestine Wanjalla, ${ }^{1}$ April Pettit ${ }^{1}$
}

'Department of Medicine, Division of Infectious Diseases, Vanderbilt University Medical Center, Nashville, Tennessee, USA

${ }^{2}$ Department of Medicine, Vanderbilt University Medical Center, Nashville, Tennessee, USA

\section{Correspondence to}

Dr Kevin Kuriakose,

kkuriakose6@gmail.com

Accepted 23 January 2017

\section{DESCRIPTION}

A woman aged 36 years with untreated AIDS presented with symptoms of abdominal pain, increasing dyspnoea with haemoptysis and weight loss. Prior to arrival in the USA, she lived in the Democratic Republic of Congo. She was afebrile, and had bilateral expiratory wheezing on examination. T-helper CD4 cell count was 106 (9\%) and HIV PCR quantification was 1146362 copies $/ \mathrm{mL}$. A CT scan revealed bilateral ground glass opacities, diffuse small bowel wall thickening and mild hepatosplenomegaly. A bronchoscopy with bronchoalveolar lavage (BAL) showed 11 nucleated cells $/ \mu \mathrm{L}$ noted $(11 \%$ neutrophils, $4 \%$ lymphocytes, $77 \%$ mononuclear cells and $8 \%$ eosinophils). BAL microscopy noted live Strongyloides larvae (video 1 and figure 1). Cytopathology studies were also notable for the presence of

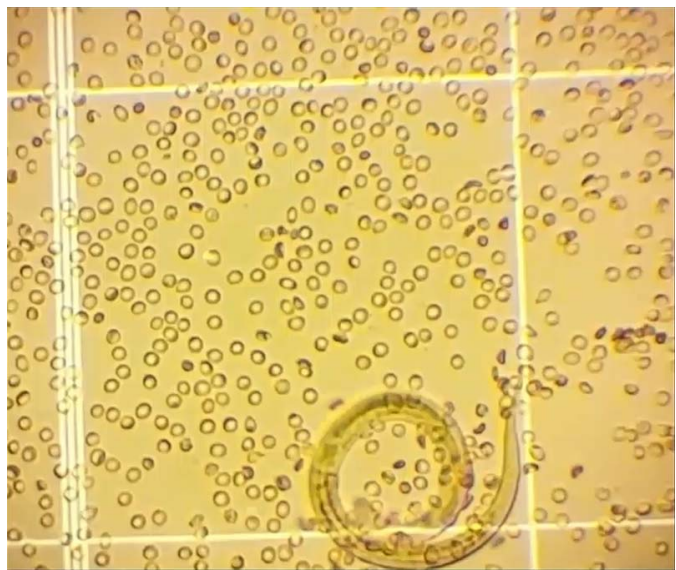

Video 1 Bronchoalveolar lavage microscopy demonstrating a live and mobile Strongyloides stercoralis larva.

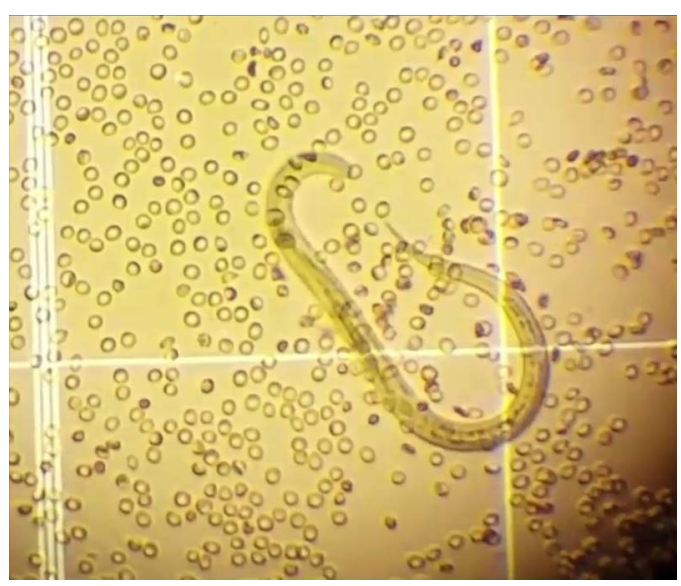

Figure 1 Bronchoalveolar lavage microscopy showing a Strongyloides stercoralis larva.

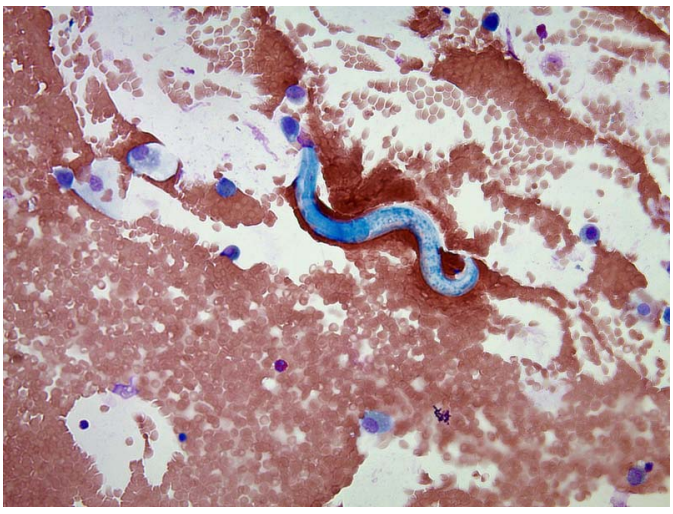

Figure 2 Lung cytopathology with Prussian Blue staining, at $\times 200$ magnification, confirming the presence of Strongyloides stercoralis.

Strongyloides stercoralis larvae (figure 2). Blood cultures grew Klebsiella pneumoniae. This clinical amalgamation of enteritis, Gram-negative rod bacteraemia and pulmonary invasion of filariform larvae is classic for Strongyloidiasis hyperinfection syndrome. She was treated with 7 days of ivermectin prior to initiation of antiretroviral therapy, and reported resolution of symptoms on follow-up.

This case highlights the importance of having a low index of suspicion for Strongyloidiasis, especially in the immunocompromised host. Steroid use, in particular, has been associated with dissemination of disease and worse outcomes. ${ }^{1}$ Often, the presenting diagnosis is septicaemia with enteric organisms, thought to be from translocation of bacteria by the larvae. ${ }^{2}$ The organisms can be detected in stool, and have been found to persist in humans for several decades since travel to an endemic area. ${ }^{3}$

\section{Learning points}

- Consider Strongyloidiasis in the differential when dealing with recurrent septicaemia with enteric organisms.

- Strongyloidiasis has been known to persist and cause recurrence of disease after initial successful treatment.

- Steroid use can be associated with dissemination and severe disease.

Acknowledgements The authors thank Stephen Raffanti, MD, William Stone, MD, and Todd Hulgan, MD.

Contributors $\mathrm{KC}$ and $\mathrm{KK}$ contributed equally in direct patient care, as well as in the compilation of this summary, literature 
search, and formatting of media. CW was this patient's primary care physician who initiated expedited workup of her persistent symptoms. CW was actively involved in the investigations ordered while inpatient. AP was the attending physician on the team, supervising patient care.

Competing interests None declared.

Patient consent Obtained.

Provenance and peer review Not commissioned; externally peer reviewed.

\section{REFERENCES}

1 Scowden EB, Schaffner W, Stone WJ. Overwhelming strongyloidiasis: an unappreciated opportunistic infection. Medicine (Baltimore) 1978;57:527-44.

2 Kassalik M, Mönkemüller K. Strongyloides stercoralis hyperinfection syndrome and disseminated disease. Gastroenterol Hepatol (N Y) 2011;7:766-8.

3 Hauber HP, Galle J, Chiodini PL, et al. Fatal outcome of a hyperinfection syndrome despite successful eradication of Strongyloides with subcutaneous ivermectin. Infection 2005;33:383-6.

Copyright 2017 BMJ Publishing Group. All rights reserved. For permission to reuse any of this content visit http://group.bmj.com/group/rights-licensing/permissions.

BMJ Case Report Fellows may re-use this article for personal use and teaching without any further permission.

Become a Fellow of BMJ Case Reports today and you can:

- Submit as many cases as you like

- Enjoy fast sympathetic peer review and rapid publication of accepted articles

- Access all the published articles

- Re-use any of the published material for personal use and teaching without further permission

For information on Institutional Fellowships contact consortiasales@bmjgroup.com

Visit casereports.bmj.com for more articles like this and to become a Fellow 